\title{
ENERGY EFFICIENCY USE OF BIOCLIMATIC FACADES IN MEDICAL BUILDINGS
}

\section{Bulakh Irina ${ }^{1}$}

DOI: https://doi.org/10.30525/978-9934-571-78-7_62

Abstract. The experience of using bioclimatic facades in the design of medical institutions in countries with high levels of quality medical services has been investigated. Scientific research in the field of design of medical buildings using energy efficient technologies and solutions are considered. Attention is paid to the problems of protection of therapeutic and preventive buildings from excessive exposure to solar energy (overheating, excessive lighting) with the possibility of individual adjustment of the indoor microclimate. The relevance of the research is connected with the world tendency of conservation of energy resources, their purposeful use, and careful attitude to the ecology of the environment. Aggravated these questions relate to an extensive city network of medical facilities that use most of the budget (own or allocated by the state) for the operating costs of the building. The study shows the percentage of financial savings in the operation of medical buildings using conventional (traditional) enclosing systems in comparison with the use of energy-efficient solutions. The economic feasibility of using bioclimatic facade systems in hospitals ranges from $20-40 \%$ savings on energy resources. The combination of the bioclimatic facade with other energy-efficient design techniques for medical facilities (the use of heat pumps, renewable energy, filtration and water reuse, etc.) will significantly increase the percentage of savings. The existing situation is characterized, the problems associated with the functioning and operation of healthcare institutions in Ukraine are highlighted, the lack of integration of modern energy-efficient solutions during modernization and design is revealed. The possibilities of thermal modernization of constructed medical institutions (insulation of walls and roofs, replacement of windows and doors with energy efficient ones, modernization of the heating system, etc.) are considered. The results of the study will be useful in the design of new

\footnotetext{
${ }^{1} \mathrm{PhD}$ of Architecture, Associate Professor at the Department of Design of the Architectural Environment, Kiev National University of Construction and Architecture, Ukraine

(C) Bulakh Irina
} 


\section{Bulakh Irina}

health facilities, modernization of medical institutions. Further study of the issues of energy efficiency of treatment-and-prophylactic institutions will allow adjusting state regulatory documents and rules intended to regulate the design and construction of health facilities.

\section{Introduction}

Today, Ukraine is actively pursuing the health care reform begun in 2015, which is gradually introducing the necessary modernization and changes in the worn and outdated system of organizing medical care to the country's population. The main directions of the reform activities of the Government of Ukraine regarding the health sector, which relate to absolutely all of its components, are set out in the National Strategy for Reforming the Health System in Ukraine for the period 2015-2020 [1].

The strategy identified the concept for reform, gave it structure and revealed the potential of versatile activities aimed at the effective modernization and development of health services. Ukrainian legislation provides for a number of laws aimed at introducing energy-efficient solutions and technologies in the design, construction and operation of buildings. These documents should help optimize the use of energy resources, including on the maintenance of health buildings [2-5]. Beginning in 2017, Ukraine adopted the Law "On the Energy Efficiency of Buildings", according to which the issue of introducing modern energy-efficient solutions to medical buildings is fixed at the state level as a requirement for execution [6].

The main and main task of all buildings that are in the field of health, care is about the life and health of people. The specified condition should be provided for in the basis of creating projects for medical buildings, as well as being maintained during the construction and subsequent operation stages. It is also necessary to take into account the fact that buildings of medical purpose serve not only for the physical placement of patients, but also should serve as an intellectual tool and assistant for those who have professionally chosen to take care of people's health and life.

The study was preceded by an analysis of the features of the architectural and town-planning organization of the health care system in leading countries (USA, France, UK, Germany, etc.) [7; 8]. Modern progressive trends in the architectural design of treatment-and-prophylactic institutions in the country's leading to the provision of medical care (Hong Kong, Singapore, United Arab Emirates, etc.) (Figure 1, Figure 2) [9] were also 

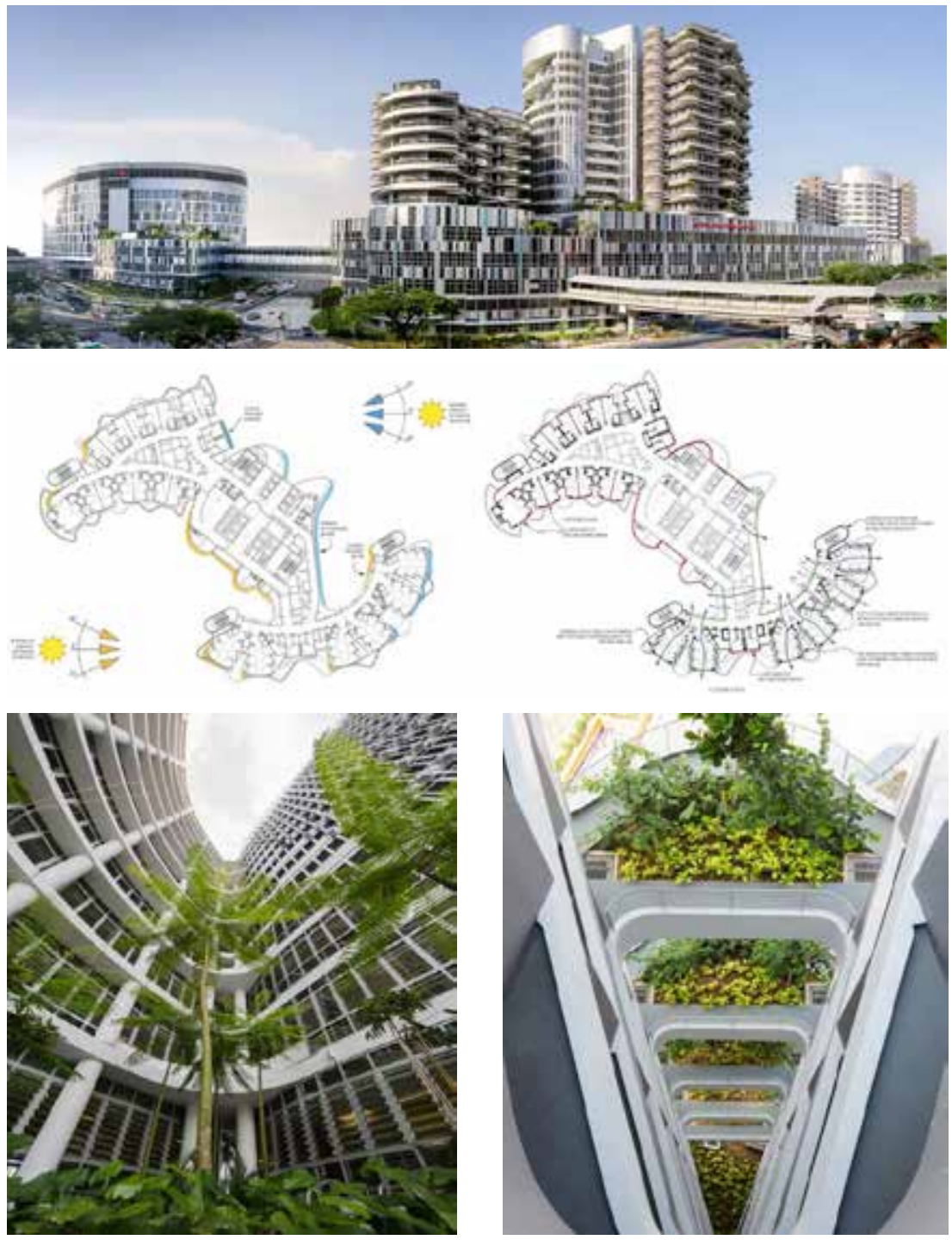

Figure 1. Bioclimatic facade system in Ng Teng Fong (NTFGH) i Jurong (JCH) Hospital, CPG Corporation, Singapore, 2015 

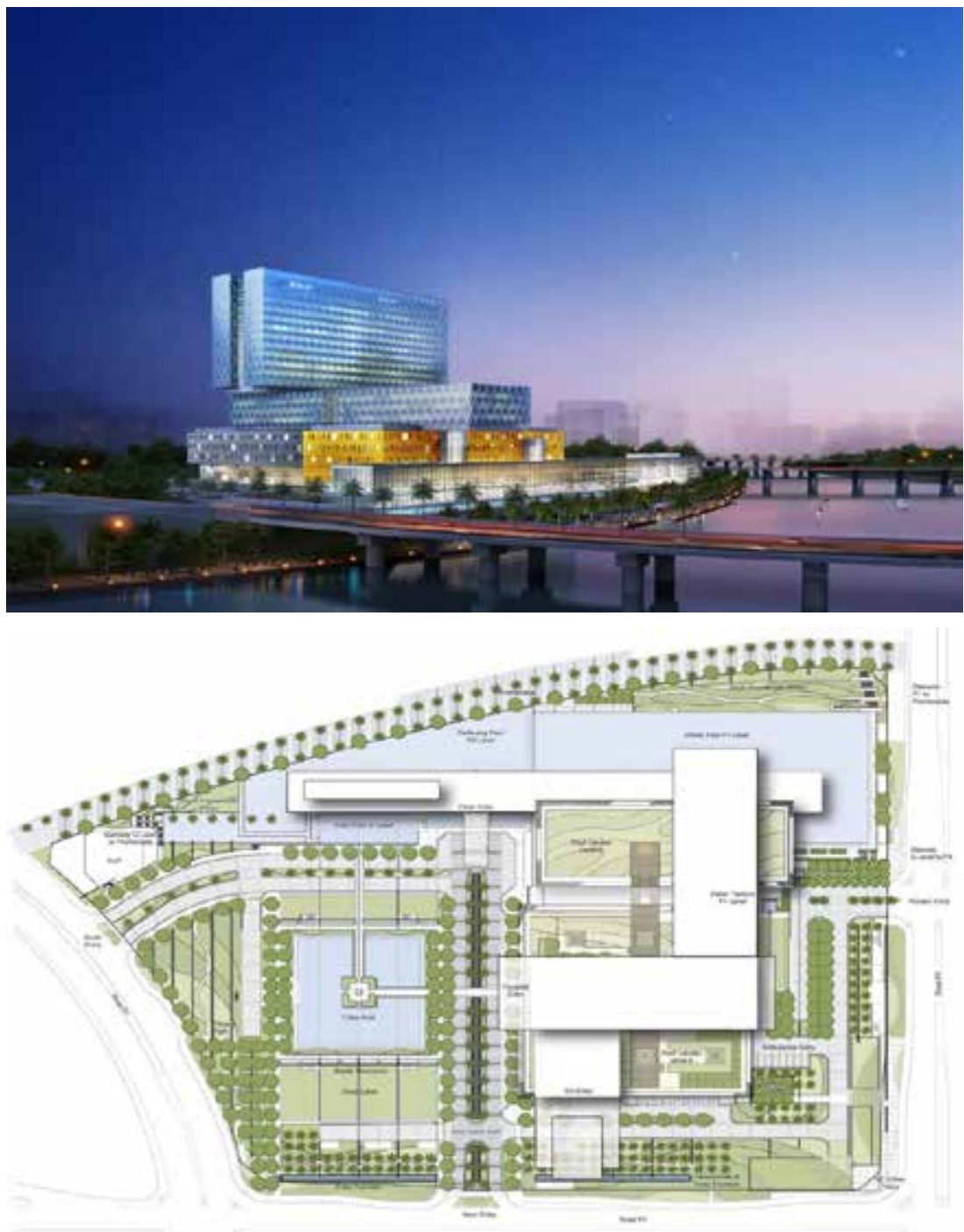

Figure 2. Bioclimatic facade system in Abu Dhabi's Cleveland Clinic, HDR Architecture, Abu Dhabi, UAE, 2013 
studied. The obtained data allowed to formulate new requirements for medical buildings, according to which outpatient clinics, medical centers, hospitals, clinics, orphanages, and nursing homes should meet a number of special requirements [10-12].

On this basis, a group of requirements is considered in detail, aimed at improving energy efficiency and energy saving of the architecture of buildings in the field of health protection in Ukraine. The relevance of the study is based on the health care reform carried out in Ukraine, new legal requirements and global trends in energy efficient design. In their combination, these factors provide an opportunity to make the necessary changes to the energy-efficient profile in the process of architectural design of objects in the healthcare sector of Ukraine.

Due to the lack of such theoretical and practical experience in the Ukrainian arsenal, the study is based on the analysis of the best examples of implementing energy-efficient solutions in leading countries by rating the level of organization of the quality of the medical sector. The relevance of the work lies in the study of the experience of using bioclimatic facades in the design of medical buildings.

\section{Literature analysis and problem statement}

Analysis of research on similar topics allowed us to select several works. The study of the durability of hydromorphous wood composites under conditions of complete weathering, conducted to develop an optimized system for the reactive shell of buildings [13]. The analysis of the energy efficiency of bioclimatic design, conducted on the example of residential buildings of the college, focused on the study of daylight and natural ventilation [14]. The authors recommend using a courtyard and a combination of balconies for apartment buildings. The study and quantitative determination of the increase in the efficiency of the use of thermal energy of a building during the installation of a ventilated facade made it possible to identify positive features of the convection process [15].

The study of the internal environment of medical buildings, as a dynamic and complex system, allowed us to identify: bio-psycho-social aspects; interaction between patients, the building and the internal environment; climate change and impact on the microclimate; energy efficiency of the internal environment [16]. The study of sustainable construction, environmental design and features of the parameters of the premises for 


\section{Bulakh Irina}

children of different ages in Mongolia allowed us to formulate requirements for the organization of children's space [17]. The results of this study can be embedded in the design of children's medical institutions. A review of the design features of medical buildings in Nigeria made it possible to identify three basic design principles that should ensure: efficiency, stability and aesthetics of health care buildings [18]. The study of the internal localization of medical equipment in hospitals by defining functional spaces allowed us to formulate a localization method that takes into account a number of factors (geometrical parameters, positioning systems and obstacles) [19]. Comparison of the main energy indicators and characteristics of public and residential buildings is made, the calculation of economic efficiency in the implementation of energy efficient technologies is given on the example of EU countries [20].

An attempt to balance the requirements of energy efficiency and indoor microclimate quality led to an alternative, inspired by nature direction in design. Its essence is in the adaptability of enclosing structures. Bionics (biomimicry) - a new direction in science that studies natural structures and their application in human life, forms conceptual solutions in architecture. With the help of modern construction technologies, innovations in the field of building materials and controlled facade components, it is possible to develop innovative facades that can respond to environmental changes and function as a living organism [21]. The enclosing structures created by nature, such as shells, leather, shells, have undergone significant changes in the process of evolution: energy consumption has decreased, but at the same time the ability to grow and reproduce has been preserved. Applying the principles of the functioning of living organisms in architecture, you can create a key component for the development of the ecological construction sector. The possibilities of using bioclimatic facade systems and their energy efficiency in the design of residential and office buildings [22] are considered. The authors of the study described the processes of the adapted building envelope to the effects of the external climate and the provision of conditions of a given microclimate in the room, borrowed from nature.

One of the most well-known and studied examples of deformation in nature is the phenomenon of opening and closing spruce cones as a reaction to changes in air humidity. This natural phenomenon was studied and borrowed for the development of the innovative facade [23]. This approach, called Meteor sensitive Architecture, involves the application of 
elastic deformation of the plywood structure in a facade system that reacts to moisture. An innovative feature of this structure is that the material reacts as a sensor and as an actuator. This material can be "programmed" to respond to the prevailing environmental conditions in various ways. Internal vascular systems present in most warm-blooded organisms form the basis for a [24] bio-adaptable window glass. The glass is equipped with a matrix of the thinnest transparent water channels, which plays the role of a micro jet heat exchanger to control the surface temperature of the glass. By regulating the flow of water in the system, dynamic temperature control is achieved. Researchers report a cooling capacity of this system at $7-9^{\circ} \mathrm{C}$ with a relatively low water flow. The next goal is to increase the heat capacity of this structure by using phase change materials at the level of the nanostructure. The problems of architectural design of medical buildings in the domestic studies of scientists during the period of the sovereignty of Ukraine were practically not considered or had a fragmentary character. The issues of introducing energy-efficient solutions to the architecture of healthcare buildings have not been carried out.

The purpose and objectives of the study. The purpose of this study is to focus the attention of architects on the implementation of energyefficient solutions for healthcare buildings. For this, examples of the use of bioclimatic facade systems in the newest medical buildings of European, Asian and other countries are considered. To achieve the goal of the research the tasks of scientific work are set:

- to characterize the condition of the Ukrainian buildings of a treatmentand-prophylactic profile, to determine their level of compliance with legal norms and requirements for the implementation of energy-efficient measures;

- identify and analyze foreign experience in the use of energy efficient technologies in the design of medical facilities;

- to study the features of the introduction of bioclimatic facade systems in architectural designs of buildings of medical institutions.

\section{Materials and methods for studying the effectiveness of the use of bioclimatic facade systems in the design of medical buildings}

The study is based on the systematization of the existing complex of foreign scientific research on the use of bioclimatic facade systems, their generalization for introduction into the health care buildings of Ukraine. 


\section{Bulakh Irina}

Conducting their own experimental development is difficult due to the initial stage of studying the issue of energy efficiency in the architecture of medical facilities. Also in Ukraine there are no proper test sites and other constraints.

\section{Methods for studying the feasibility of using bioclimatic facades in medical buildings}

The study is based on a systematic approach, which allows us to consider the architectural design of buildings of therapeutic and preventive purposes as a process of organizing the internal and external environment for a complex of medical events. These actions should be aimed at restoring the patient's lost level of health. Ensuring a comfortable thermal regime, improved microclimate indicators for patients and for medical personnel are an integral part of the healing process. In combination with the low level of operating costs of a medical building, compliance with environmental standards, and rapid return on investment, the feasibility of introducing bioclimatic facades into health care buildings significantly increases. The method of historical analysis was applied to summarize the architectural and town-planning characteristics and medical institutions of Ukraine. To study the state of the architecture of medical facilities, a method of qualitative and quantitative analysis, statistical data was applied. In the study of foreign experience in the design and operation of health facilities, an analysis of innovative design solutions and trends was carried out. To solve individual issues, the methods of statistical and comparative analysis, field surveys, analysis of literature and information sources were used.

\section{The results of research on the use of bioclimatic facades in the design of health care buildings}

The energy efficiency requirements of medical buildings include: comfortable thermal conditions and microclimate; minimum operating costs; environmental standards; quick return on investment. The main part of medical buildings in the post-Soviet space is constituted by architectural objects built in 1950-1980. This time period is characterized by the planned development of the national economy, standard design and the desire to maximize the network of medical institutions. Such a project approach was associated with the need to provide medical care to a maximum percentage of the population. The powerfully developed economy of the country during 
this period allowed ignoring the issues of operating costs for the further maintenance of the health care buildings. The issues of building energy consumption did not have such global significance. Subsequent changes associated with the acquisition of sovereignty of Ukraine, prolonged political and economic instability, as well as many other factors led to a complete lack of attention to the timely modernization of medical facilities in our country. The global crisis of energy resources, in combination with the internal and external problems of Ukraine, had a special impact on the significant cost sector for the maintenance of therapeutic buildings. Most of the allocated funding for medical facilities is spent on the energy consumption of obsolete medical buildings constructed of concrete panels, glazed according to the norms of 70 years ago.

Thermal modernization of existing medical buildings includes: thermal insulation of walls and roofs; replacement of windows and doors with energy saving ones; lighting upgrade; energy consumption monitoring; individual regulation of heating depending on weather conditions. Considering the issues of designing new medical facilities in the aspect of energy-efficient technologies, a significant range of innovative solutions is revealed. Their use allows to reduce operating costs, reduce the need for energy resources, use renewable energy sources. A similar approach can be observed in medical buildings in Singapore, Hong Kong, the United Arab Emirates and other countries that are progressive in the field of health care [25]. One of the key issues for the energy efficient design of medical buildings is protection from solar heat exposure. Consideration of the solar factor can significantly increase the microclimate and reduce operating costs, which is made possible through the use of bioclimatic facade systems. Examples of the use of bioclimatic facades in medical buildings are: National University Hospital in Singapore (Figure 3), Jean Bernard Hospital in France (Figure 4), Samarito Hospital in Brazil (Figure 5), Barts Hospital in London (Figure 6), Hong Kong Sanatorium and DELUXE Hospital (Figure 7).

The facade of the architectural object performs the function of the building envelope acting as an interface between the external environment and the internal volume of the building. The external environment is characterized by dynamic climatic conditions, which vary depending on the state of the weather, the time of day and the season of the year. The internal environment provides for the organization of the microclimate of the building, comfortable for people inside it. The attention of 


\section{Bulakh Irina}

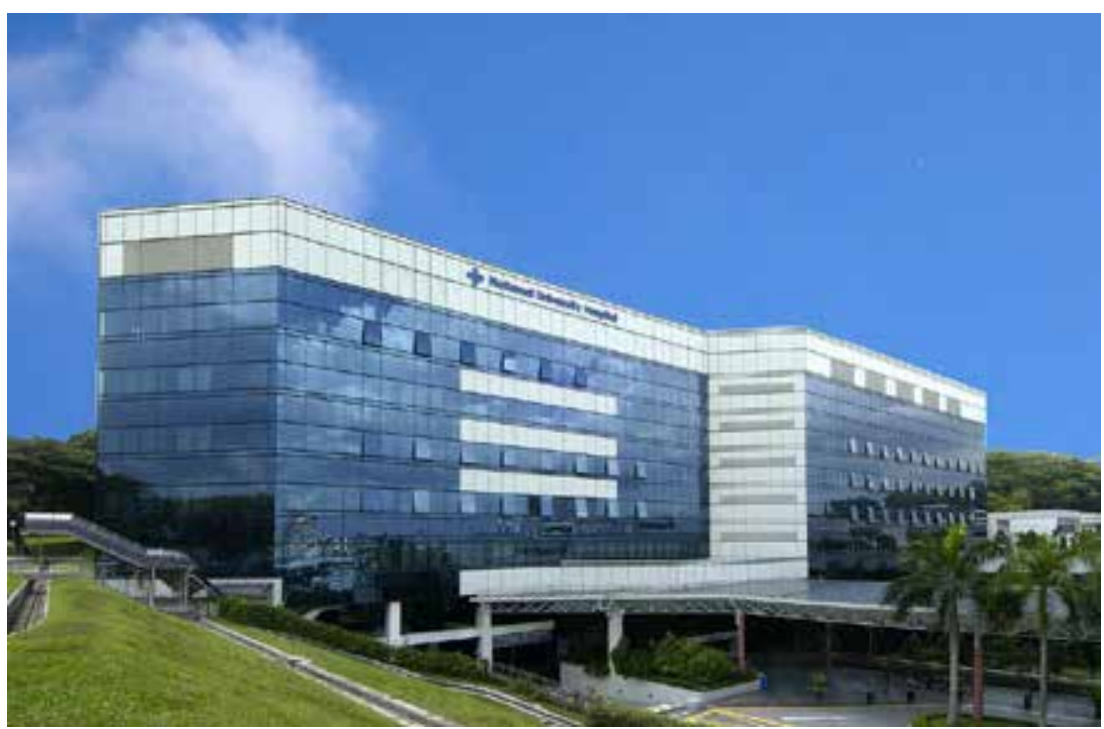

Figure 3. Bioclimatic facade system in National University Hospital, DP Architect, 2010, Singapore

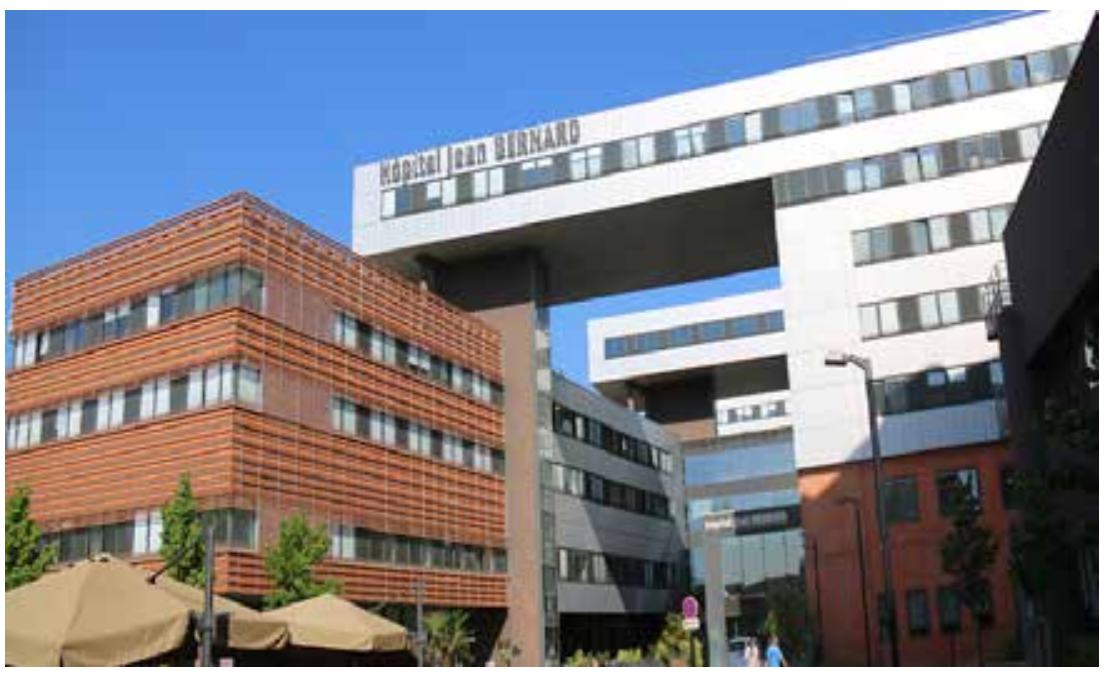

Figure 4. Bioclimatic facade system in Jean Bernard Hospital, Groupe 6, France, 2010 
Chapter «Architecture»

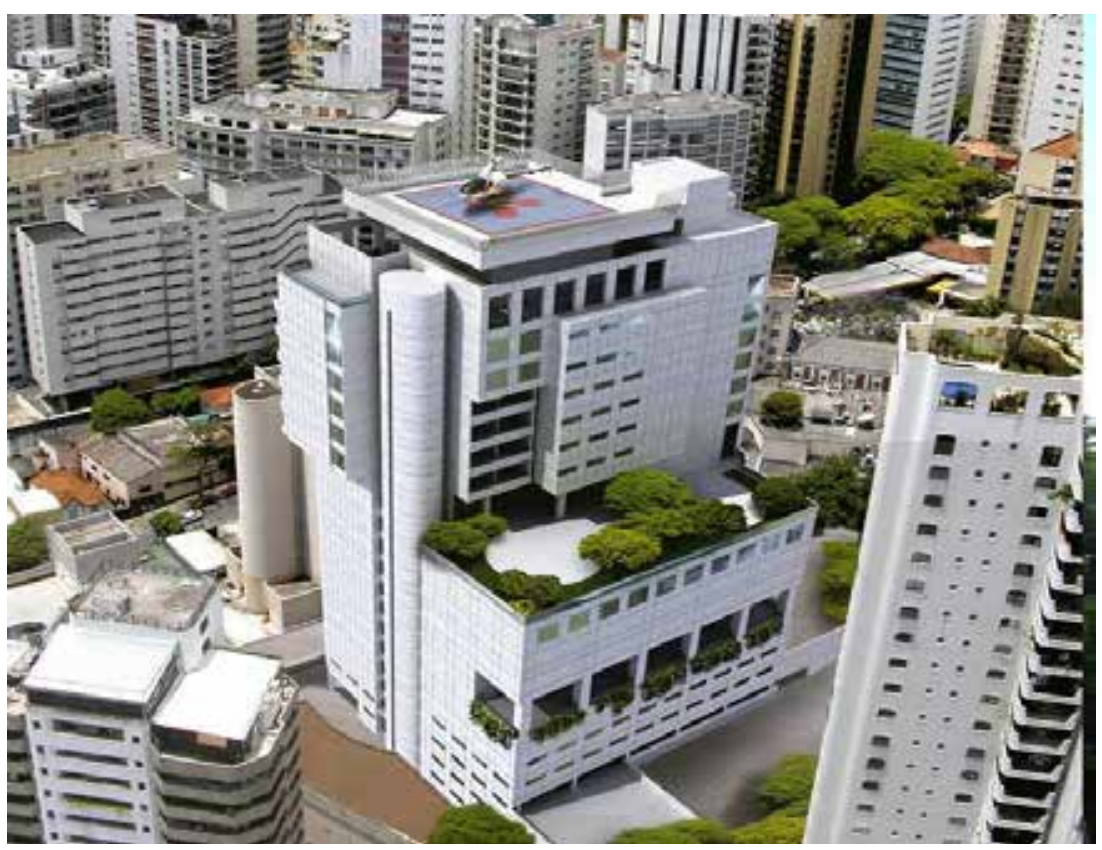

Figure 5. Bioclimatic facade system in Samarito Hospital, Brazil, 2009

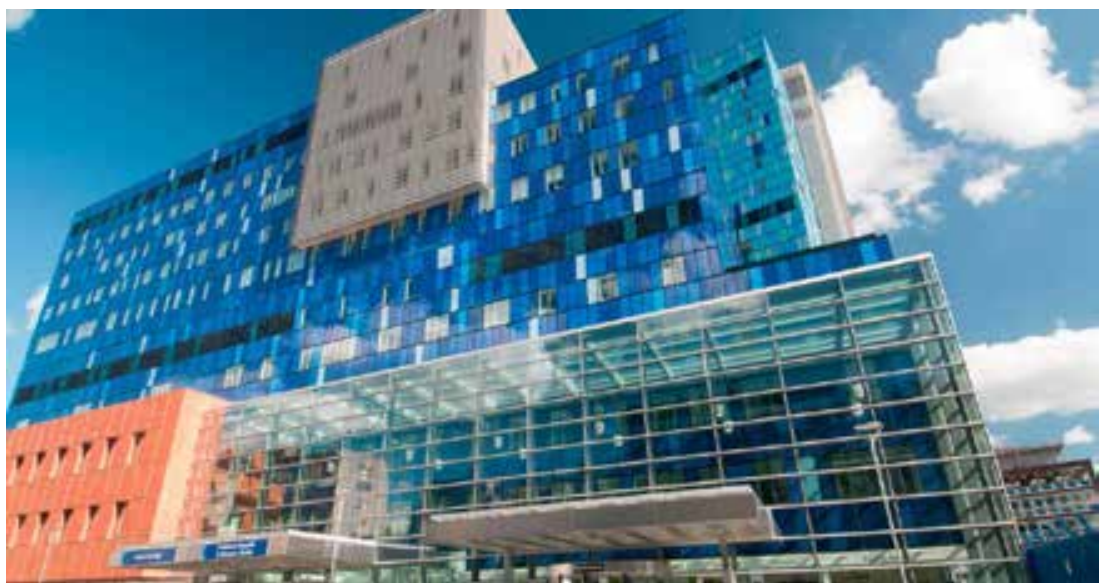

Figure 6. Bioclimatic facade system in Hospital Barts, HOK, UK, 2010 


\section{Bulakh Irina}
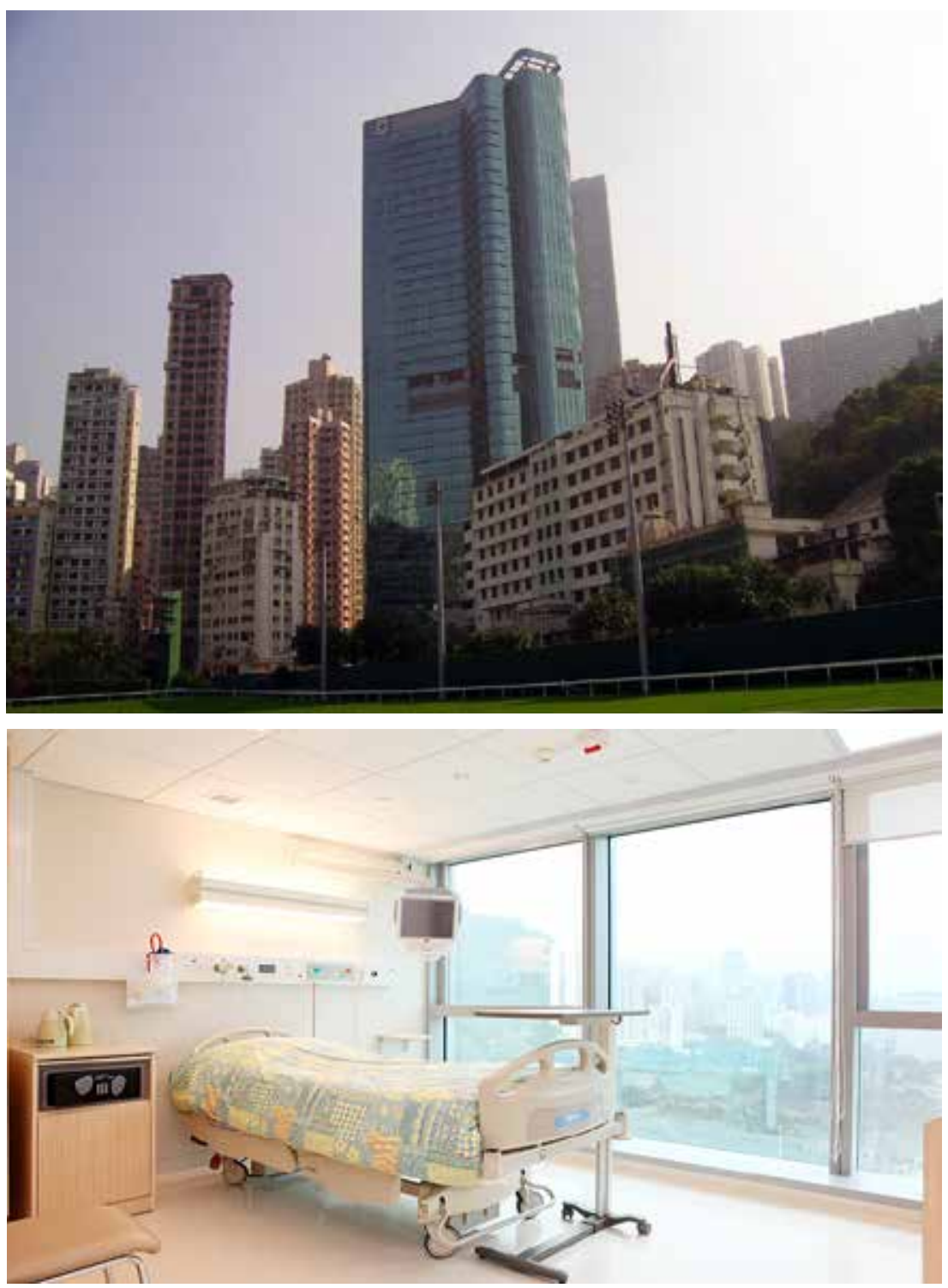

Figure 7. Bioclimatic facade system in Hong Kong Sanatorium and DELUXE Hospital, Cristalla Designs \& Contracting Ltd, Hong Kong, 2008 
architects and engineers to the preservation of the balance of the ecology of the environment, the responsibility for anthropogenic processes, the exhaustion of energy resources allowed us to create new technological solutions. An example of such innovations is the bioclimatic facade system. The bioclimatic facade is a "living membrane" of a building that is capable of constant adaptation to changes in the external environment to ensure and maintain a comfortable internal environment of the building (Figure 8).
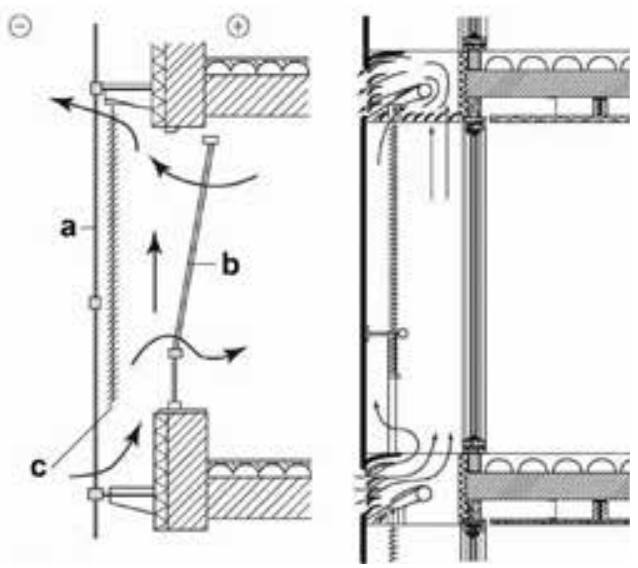

Figure 8. The principal structural diagram of the bioclimatic facade with the device of sun protection and natural ventilation (air intake and air removal): a - single glazing ESG; b - double glazing; $c$ protection of the internal environment from direct wind and sunlight

Issues of regulatory regulation of the amount and frequency of sunlight are associated with isolation. Excessive intake of solar energy in the summer period leads to overheating of the building, the need for air conditioning, which affects operating costs. The negative impact of the processes of excessive solar exposure as a result of the increase in average annual temperatures we have seen in recent years. However, the availability of sunlight and heat in the required calculated amounts are crucial for medical buildings. «Natural lighting reduces depression among patients, improves sleep and heart rate, which, in turn, reduces anxiety, relieves pain and improves working conditions for staff» [26]. 


\section{Bulakh Irina}

A significant position in the device of a medical building with a bioclimatic facade is the optimal orientation of the windows. Windows are both a source of heat and light, and also contribute to heat loss. This is due to the fact that the glazing and window frames are less thermally insulated than the walls and roof. In the northern hemisphere of the earth, the walls oriented to the south are most potential for using the energy of the sun, and in the southern hemisphere the opposite. Maximum implementation of window orientation in the design of medical buildings will allow the use of solar energy for natural heating and lighting (Figure 9).
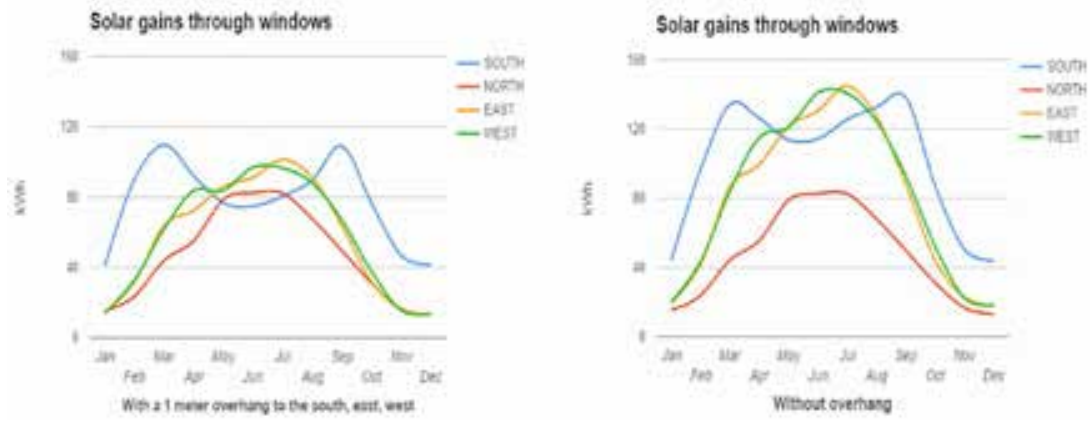

\section{Figure 9. Energy potential of using optimal orientation of windows in bioclimatic facade systems}

Based on these characteristics, it is recommended when using bioclimatic facades in medical buildings to calculate the total area of windows as $20 \%$ of the usable area of the building. The distribution of the glazing of a medical building, in terms of energy efficiency, should be as follows: $50 \%$ to the south, $20-0 \%$ to the east, $15 \%$ to the west and $0-10 \%$ to the north. These values may change when taking into account regional peculiarities of the design territory. With the introduction of bioclimatic facade systems, which provide for the presence of controlled sun-protection devices, the design of medical buildings makes it possible to achieve the necessary adaptation properties to meet the individual needs of patients and staff. Protection from sun exposure, as a rule, involves the use of two levels: external sun protection (roller blinds, external horizontal blinds, roller blinds or screen) and internal sun protection (photo blocking roller blinds). The integrated weather station allows you to automatically ensure in advance the protection of the medical building in case of hurricane, squall, snowfall or icing. 
Increasing thermal and visual (visual) comfort for patients is becoming an integral part of a set of therapeutic measures that are diversified to return the necessary positive level of health. Through the use of intelligent control systems, the patient is able to individually control the sunscreen devices in the ward, without getting out of bed and without the help of staff, in order to adjust the level of natural light and create a comfortable, private atmosphere.

Helping medical personnel to create the best working conditions is achieved through various sensors, timers, centralized control, which helps avoid repetitive tasks, such as manually opening and closing sun-protection devices. The possibility of providing individual visual comfort for work and treatment is also achieved. For various medical offices, individual requirements for the level of illumination are put forward: in operating rooms, the intensity of illumination is maximum, and to study X-ray images, it is necessary to adjust the degree of illumination.

Improving the energy efficiency of medical buildings is also justified by the fact that they use 3-5 times more energy than the average commercial building [27]. This aspect is aggravated by the fact that the energy supply in medical institutions must be stable and uninterrupted. The progressive global experience of saving energy in medical buildings is based on dynamic protection, which does not have to choose between the comfort of patients, staff and the energy efficiency of a building. Intelligent systems used reduce energy consumption by: actively using natural lighting, minimizing heat loss in winter, reducing the heating of rooms from solar energy in the summer season.

Dynamic sun protection, as the basis of the bioclimatic façade principle of operation, is a high-tech system for controlling external and internal sun protection. This system receives operational information from groups of sensors (solar radiation, wind, temperature, presence, etc.) and regulates the microclimate of the room in accordance with the specified parameters. Dynamic sun shading should incorporate shade control and sun movement. Tracking the movement of the sun will allow you to adjust the slats of the blinds in accordance with the angle of incidence of sunlight. Shadows cast by adjacent buildings or buildings of a medical building are mobile. Their changes occur depending on the time of day and the location of the building. The shading from external conditions has a noticeable effect on the natural lighting of the premises. Three-dimensional model of a medical building, 


\section{Bulakh Irina}

taking into account: the architecture and geographical location of the building; the number and location of windows; the location of neighboring buildings and the path of the sun relative to the building, in combination with sensors, make it possible to predict the dynamics of sun protection. Thanks to this approach, sun protection devices can only be lowered on those windows in which the sun really shines.

The introduction of energy-efficient systems in health care buildings is a profitable and expedient investment, which in the shortest possible time allows for the profitability of a medical institution. As a rule, modern energy efficient solutions are easily operated and integrated into other systems. According to research, investments in an automated sun-protection system from $1 \%$ to $2 \%$ of the total investment in a medical building can achieve energy savings from $20 \%$ to $40 \%$ [28]. The results of the effectiveness of the use of automated sunscreen devices in health care buildings are given in Table 1.

Table 1

\section{Energy saving medical building with the use of automated sun protection devices (data Lund university)}

\begin{tabular}{|c|c|c|c|}
\hline A country & $\begin{array}{c}\text { Consumption } \\
\text { electricity (annual) }\end{array}$ & $\begin{array}{c}\text { Stress on air } \\
\text { conditioners (in } \\
\text { watts) }\end{array}$ & $\begin{array}{c}\text { Total savings on } \\
\text { running costs } \\
\text { (annual, per } \\
1 \mathrm{~kW} / \mathrm{h} \text { ) }\end{array}$ \\
\hline $\begin{array}{c}\text { Paris } \\
\text { (France) }\end{array}$ & $\begin{array}{c}39.6 \% \text { decrease } \\
\text { (from } 1231 \mathrm{~kW} / \mathrm{h} \text { to } \\
743 \mathrm{~kW} / \mathrm{h} \text { ) }\end{array}$ & $\begin{array}{c}39.7 \% \text { decrease } \\
\text { (from } 2306 \mathrm{~W} \text { to } \\
1390 \mathrm{~W} \text { ) }\end{array}$ & $\begin{array}{c}\text { With a price of } \\
1 \mathrm{~kW} / \mathrm{h}=€ 0.11 \\
\text { Total: } € 53.68\end{array}$ \\
\hline $\begin{array}{l}\text { Saopaolo } \\
\text { (Brazil) }\end{array}$ & $\begin{array}{c}28.52 \% \text { decrease } \\
(\text { from } 2461 \mathrm{~kW} / \mathrm{h} \text { to } \\
1759 \mathrm{~kW} / \mathrm{h})\end{array}$ & $\begin{array}{c}38.53 \% \text { decrease } \\
\text { (from } 2964 \mathrm{~W} \text { to } \\
1822 \mathrm{~W} \text { ) }\end{array}$ & $\begin{array}{c}\text { With the price of } \\
1 \mathrm{~kW} / \mathrm{h}=\mathrm{R} \$ 0.3 \\
\text { Total: } \mathrm{R} \$ 210.6\end{array}$ \\
\hline $\begin{array}{l}\text { Barcelona } \\
\text { (Spain) }\end{array}$ & $\begin{array}{c}40.3 \% \text { decrease } \\
\text { (from } 2689 \mathrm{~kW} / \mathrm{h} \text { to } \\
1604 \mathrm{~kW} / \mathrm{h} \text { ) }\end{array}$ & $\begin{array}{c}42.05 \% \text { decrease } \\
\text { (from } 2647 \text { watts to } \\
1.534 \text { watts) }\end{array}$ & $\begin{array}{c}\text { With a price of } \\
1 \mathrm{~kW} / \mathrm{h}=€ 0.14 \\
\text { Total: } € 151.90\end{array}$ \\
\hline $\begin{array}{l}\text { Stockholm } \\
\text { (Sweden) }\end{array}$ & $\begin{array}{l}44.98 \% \text { decrease } \\
\text { (from } 1,445 \mathrm{~kW} / \mathrm{h} \\
\text { to } 795 \mathrm{~kW} / \mathrm{h} \text { ) }\end{array}$ & $\begin{array}{c}43.95 \% \text { decrease } \\
\text { (from } 2189 \mathrm{~W} \text { to } \\
1,227 \mathrm{~W} \text { ) }\end{array}$ & $\begin{array}{c}\text { With a price of } \\
1 \mathrm{~kW} / \mathrm{h}=€ 0.15 \\
\text { Total: } € 91\end{array}$ \\
\hline \multicolumn{4}{|c|}{$\begin{array}{l}\text { Initial data: chamber } 25 \mathrm{~m}^{2} \text {, glazing } 7 \mathrm{~m}^{2} \text { (double glazing Low-E, facade walls } \\
\left.U=0.33 \mathrm{~W} / \mathrm{m}^{2} \mathrm{~K}\right) \text {. Fifty south oriented chambers explored. Domestic roller blinds } \\
\text { made of gray PVC. Calculations are made for a building with and without } \\
\text { sun protection, } 1 \text { person per room, artificial light } 250 \mathrm{~W} \text { per room. }\end{array}$} \\
\hline
\end{tabular}


There are various ways to control the bioclimatic facade system: by timers, by commands from a weather station with sensors, in manual mode from wall switches or remote controls. When equipping chambers, common areas (halls, corridors, etc.), cabinets and other rooms, it is necessary to take into account: the type and number of sun-protection devices, their division into various zones, functions performed, control methods, etc.

Discussion of the results of the study of energy-efficient solutions in the design of medical buildings. This study is a starting point in the study of the use of energy-efficient technologies in the design of health care buildings. The main advantage of the work is drawing the attention of designers to the existing advanced experience in the implementation of bioclimatic facades in medical buildings. The work may be useful in the reconstruction and modernization of existing health care buildings, as well as in the design of new medical buildings [29-33]. The disadvantages of the work include the lack of practical application in Ukraine; experimental studies are difficult due to the lack of construction of new medical complexes. As part of further research, it is planned to focus on the problem of preserving the ecology of the environment when designing medical buildings and complexes. Trends will be considered to return to natural ventilation, the feasibility of a heating system, the use of energy-efficient materials, structures, spacespatial and planning solutions, taking into account the climatic factors of the environment.

In the Soviet period of Ukraine, medical buildings were designed cheaply and quickly, according to standard designs, excluding planning and energy efficiency of the building [30]. Today, by inertia, we largely continue to design and build, based on a set of rules and regulations that relate to the past century. Gradually, it comes to the realization that the value of any architectural structure will be much higher, subject to the achievement of uniqueness and originality through the introduction of energy efficient techniques. Buildings appear in the world that can provide a microclimate without absorbing natural non-renewable energy sources (coal, oil products, peat, etc.).

The development of regulatory requirements for the design of medical buildings with regard to energy efficiency is also planned as a continuation of this study. Medical buildings designed to restore, preserve and maintain the level of public health are a developed city-planning network that covers the entire space of modern cities. 


\section{Bulakh Irina}

The design of treatment-and-prophylactic facilities should take into account the characteristic features of energy-saving buildings, which include the ratio of useful areas to the area of enclosing structures. In the language of pure geometry of a spatial composition of a building, a cube or cylinder is the most effective, provided that the same ratio of height and diameter is used. The compact form of the building is less dependent on spatial orientation. In the case of passive use of solar energy, the southern orientation of the building is most favorable. Thus, the study of planning and volumetric-spatial forms of medical buildings, in terms of the best energy efficiency indicators, can be a continuation of this study. The use of foreign experience in implementing energy-efficient solutions in the design of medical facilities requires comprehensive analysis and adaptation to the climatic conditions of a particular region, which is also a promising area of study.

\section{Conclusions}

A discrepancy was revealed between Ukrainian health care buildings and international standards for energy efficiency of buildings, domestic legislation and requirements for the implementation of energy efficiency measures.

Analyzed the foreign experience of using energy-efficient solutions in the design of medical buildings, among which the technology of bioclimatic facade systems is of particular importance. Using these systems allows you to save on the operation of a medical building then 20 to $40 \%$ of energy.

The features of bioclimatic facades in the design of health care buildings were studied. These include: the possibility of individual and centralized climate control, regulation of solar light and heat energy, the use of natural ventilation, reduction of operating costs. These properties of bioclimatic facades are controlled by intelligent automated systems capable of responding to changes in climatic conditions in advance.

\section{References:}

1. National strategy for reforming the health system in Ukraine for the period 2015-2020 years. Available at: http://moz.gov.ua/strategija

2. Law of Ukraine «On Electricity» (1994). Information from the Verkhovna Rada of Ukraine, 30, 283.

3. Law of Ukraine «On Alternative Energy Sources» (2003). Information from the Verkhovna Rada of Ukraine, 24, 155. 


\section{Chapter «Architecture»}

4. Law of Ukraine «On Combined Production of Thermal and Electric Energy (cogeneration) and Utilization of Renewable Energy Potential» (2005). Information from the Verkhovna Rada of Ukraine, 20, 278.

5. Law of Ukraine «On Energy Saving» (1994). Information from the Verkhovna Rada of Ukraine, 30.

6. Law of Ukraine «On Energy Efficiency of Buildings» (2017). Information from the Verkhovna Rada, 33, 359.

7. Bulakh I. (2016). Landscape and water as the basis of contemporary world trends in the design of medical facilities. Modern Problems of Architecture and Urban Development, 46, 392-396.

8. Bulakh I. (2017). Prerequisites for reorganization of the network of children's medical institutions of Ukraine. Modern Problems of Architecture and Urban Development, 47, 444-450.

9. Bulakh I. (2018). Modern foreign experience in designing energy-efficient hospitals (Singapore experience). Modern Problems of Architecture and Urban Development, 50, 332-440.

10. Bulakh I. (2018). The main trends in organization of architectural environment of medical institutions. Web of Scholar, 5(23), 1, 59-62.

11. Bulakh I. (2017). Problem field of tasks of reorganization of the network of children's medical institutions of Ukraine. Urban Planning and Territorial Planning, 63, 45-51.

12. Bulakh I. (2018). Designing modern childcare facilities taking into account the historical context of the urban architectural environment (UK experience). European network for academic integrity. The development of technical sciences: problems and solutions: Conference Proceedings, April 27-28, 2018. Brno: Baltija Publishing, 187-190.

13. Holstov A., Farmer G., Bridgens B. (2017). Sustainable Materialisation of Responsive Architecture. Sustainability, 9, 435. doi: 10.3390/su9030435

14. Salleh H., Mohamed Sabli N.A., Shah Ali A., Alshawi M.A. (2011). Performance Evaluation for IT/IS Implementation in Organisation: Preliminary New IT/IS Capability Evaluation (NICE) Model. Journal of Design and the Built Environment, 9(1), 75-88.

15. Bengochea Escribano M. A., López Jiménez P. A., López Patiño G., Mora Pérez M. (2011). Cuantificación de la eficiencia de la fachada cerámica ventilada mediante técnicas de la mecánica de fluidos computacional. Boletín de la Sociedad Española de Cerámica y Vidrio, 50(2), 99-108. doi: 10.3989/cyv.142011

16. Wierzbicka A., Pedersen E., Persson R., Nordquist B., Stålne K., Gao C., Harderup L.-E., Borell J., Caltenco H., Ness B., Stroh E., Li Y., Dahlblom M., Lundgren-Kownacki K., Isaxon C., Gudmundsson A., Wargocki P. (2018). Healthy Indoor Environments: The Need for a Holistic Approach. International Journal of Environmental Research and Public Health, 15(9), 1874. doi: 10.3390/ijerph15091874

17. Ren K., Xu L. (2017). Dataset on energy efficiency assessment and measurement method for child-friendly space in cold residential area. Data in Brief, 14(C), 148-155. doi: 10.1016/j.dib.2017.07.032

18. Fadamiro J.A., Adedeji J.A. (2013). An overview of collapse of buildings in Nigeria: a medico-spatial analysis. Journal of Architecture and Built Environment, $40(2), 53-62$. 


\section{Bulakh Irina}

19. Van der Ham M. F. S., Zlatanova S., Verbree E., Voûte R. (2016). Real time localization of assets in hospitals using quuppa indoor positioning technology. Remote Sensing and Spatial Information Sciences, IV-4/W1, 105-110. doi: 10.5194/ isprs-annals-IV-4-W1-105-2016

20. Spikman M., Dick Van Dijk. (2009). Comparison of the energy performance of buildings in the EU. Energy saving, 5, 43-45.

21. Loonen R. C. G. M., Trčka M., Costola D., Hensen J. L. M. (2013). Climate Adaptive Building Shells: State of the Art and Future Challenges. Renewable and Sustainable Energy Reviews, 25, 483-493. doi: 10.1016/j.rser.2013.04.016.

22. Loonen R., Khairulina A., Hensen J. (2014). Bioadaptive shell of buildings. High-tech buildings, 3(3-3), 50-57.

23. Reichert S., Menges A., Correa D. (2015). Meteorosensitive Architecture: Biomimetic Building Skins Based on Materially Embedded and Hygroscopically Enabled Responsiveness. Computer-Aided Design, 60, 50-59. doi: 10.1016/j.cad.2014.02.010

24. Hatton B. D., Wheeldon I., Hancock M. J., Kolle M., Aizenberg J., Ingber D. B. (2013) An Artificial Vasculature for Adaptive Thermal Control of Windows. Solar Energy Materials and Solar Cells, 117, 429-436. doi:10.1016/j.solmat.2013.06.027.

25. Bloomberg. World Ranking on the effectiveness of health systems in 2017. Available at: https://www.bloomberg.com

26. The Centre for Health Design. Available at: https://www.healthdesign.org

27. Now or Never: IEA Energy Technology Perspectives 2008 shows pathways to sustained economic growth based on clean and affordable energy technology. Available at: https://www.iea.org

28. Energy saving by adding a glass-façade to a brick building. Available at: https://www.lunduniversity.lu.se/lup/publication/e3918b4c-7f6c-4fd7-8c42da9ac8e94c71

29. Bulakh I. (2018). Rehabilitation and Relaxation centre for participants in hostilities. Problems of Theory and History of Architecture of Ukraine, 18, 207-213.

30. Bulakh I. (2018). Architectural and urban network of health care institutions in Kyiv. Internauka, 14(54), 11-13.

31. Bulakh I.V. (2018). Analysis of scientific research in the field of architectural and urban designing of children healing institutions. Colloquium-journal. Warszawa, № 10(21). Vol. 7, pp. 5-8.

32. Bulakh I.V. (2018). Analysis of scientific research in the aspect of architectural and urban design of health facilities. Scientific Herald of Construction. Kharkov, T. 93, 3. 29-36.

33. Bulakh I.V. (2009). The symbol and symbolism in philosophical and theoretical studies, in art and architecture. Bulletin of the Kharkov State Academy of Design and Arts. Kharkiv, 7, pp. 12-16. 